\title{
PENINGKATAN HASIL BELAJAR PESERTA DIDIK PADA MATERI OPERASI HITUNG BILANGAN PECAHAN DENGAN MENGGUNAKAN MODEL PEMBELAJARAN KOOPERATIF TIPE TEAM ASSISTED INDIVIDUALIZATION DI KELAS VII SMP NEGERI 4 AMBON
}

\author{
Tressya Litaay \\ ${ }^{1,2,3}$ Program PPG Bidang Studi Pendidikan Matematika FKIP, Universitas Pattimura \\ Jalan Ir. M. Putuhena, Kampus Unpatti, Poka, Ambon, Indonesia \\ e-mail: echalitaay@gmail.com;
}

\begin{abstract}
Abstrak
Pembelajaran matematika seharusnya melibatkan partisipasi peserta didik agar peserta didik lebih aktif dan mudah mengerti materi yang dipelajari. Pendidik harus mengubah cara mengajar dan mampu meramu pembelajaran menarik dan efektif, sehingga mampu mendorong peserta didik untuk berpartisipasi aktif dalam proses pembelajaran. Salah satu pilihan model pembelajaran kooperatif yang dapat pendidik terapkan dalam pembelajaran di kelas adalah model pembelajaran kooperatif tipe Team Assisted Individualization. Penelitian ini bertujuan untuk meningkatkan hasil belajar peserta didik pada materi operasi hitung bilangan pecahan melalui model pembelajaran kooperatif tipe Team Assisted Individualization di kelas VII SMP Negeri 4 Ambon. Subjek penelitian adalah peserta didik kelas VII1 tahun ajaran 2018/2019 dengan jumlah 30 orang. Penelitian ini adalah Penelitian Tindakan Kelas yang berhasil meningkatkan hasil belajar peserta didik pada materi operasi hitung bilangan pecahan dalam 2 siklus dengan persentase ketuntasan pada siklus I sebesar $41 \%$ dan persentase ketuntasan pada siklus II sebesar $73 \%$.
\end{abstract}

Kata Kunci: hasil belajar, pecahan, pembelajaran kooperatif, team assisted individualization

\section{THE IMPROVEMENT OF STUDENTS ACHIEVEMENT ON THE TOPIC OF FRACTIONS OPERATIONS BY USING COOPERATIVE LEARNING TYPE TEAM ASSISTED INDIVIDUALIZATION AT SMP NEGERI 4 AMBON}

\begin{abstract}
Mathematics learning should involve the participation of students so they can be more active and easy to understand the topic they have been studied. Teachers must change the way of teaching and be able to mix interesting and effective learning, so it can encourage students to be active participants in the learning process. One of the choices of cooperative learning models that teachers can apply in the classroom is the Team Assisted Individualization. This research aims to improve the learning outcomes of students in fractional counting operations through cooperative learning models type Team Assisted Individualization in VII Class, SMP Negeri 4 Ambon. The research subjects were 30 students of VII1 grade students on the 2018/2019 school year. This research is a Class Action Research has succeeded to improving student learning outcomes in fractional counting operations in 2 cycles with a percentage of completeness in the first cycle is $41 \%$ and the percentage of completeness in the second cycle is $73 \%$.
\end{abstract}

Keywords: learning outcomes, fractions, cooperative learning, Team Assisted Individualization

\section{Pendahuluan}

Matematika merupakan salah satu ilmu dasar yang berperan penting dalam perkembangan ilmu pengetahuan dan teknologi. Pembelajaran matematika di sekolah diharapkan mampu mempersiapkan peserta didik untuk menghadapi 
permasalahan matematika yang akan terjadi di dalam kehidupan mereka. Pada kenyataannya, peserta didik sering merasa bosan dan tidak aktif saat mengikuti pembelajaran matematika. Hal ini dikarenakan oleh proses belajar mengajar yang begitu monoton dan dikuasai oleh pendidik.

Berdasarkan hasil observasi peneliti di SMP Negeri 4 Ambon pada tanggal 02 Agustus 2018, pendidik cenderung mengajar dengan suasana yang tampak tegang, sehingga peserta didik takut untuk menjawab ataupun memberikan pertanyaan. Selain itu, sikap pendidik yang kaku membuat peserta didik enggan untuk menyampaikan pendapat. Peserta didik juga mengakui bahwa pendidik menjelaskan begitu cepat dan tidak banyak memberikan akses bagi peserta didik untuk bergerak (bertanya, menyampaikan pendapat, dan lain sebagainya).

Pembelajaran matematika seharusnya melibatkan partisipasi peserta didik agar peserta didik lebih aktif dan mudah mengerti materi yang dipelajari. Untuk itulah, pendidik harus mengubah cara mengajar dan mampu meramu pembelajaran menarik dan efektif, sehingga mampu mendorong peserta didik untuk berpartisipasi aktif dalam proses pembelajaran.

Model pembelajaran yang dapat diterapkan oleh pendidik ialah model pembelajaran kooperatif. Menurut Trianto (2009: 56) model pembelajaran kooperatif merupakan model pembelajaran dalam kelompok yang melibatkan peserta didik bekerja sebagai sebuah tim untuk menyelesaikan tugas-tugas yang diberikan. Konsep model pembelajaran kooperatif muncul dari pemikiran bahwa peserta didik akan lebih mengerti pelajaran yang didapat jika mereka saling berdiskusi dengan peserta didik lain.

Model pembelajaran kooperatif merupakan komponen utama dalam Kurikulum 2013. Dengan demikian, melalui penerapan model kooperatif maka diharapkan peserta didik dapat termotivasi untuk belajar, menyampaikan pendapat dan berinteraksi dengan teman, sedangkan pendidik hanya berperan sebagai fasilitator. Salah satu pilihan model pembelajaran kooperatif yang dapat pendidik terapkan dalam pembelajaran di kelas adalah model pembelajaran kooperatif tipe Team Assisted Individualization.

Model pembelajaran kooperatif tipe TAI adalah model pembelajaran yang sebagian besar aktivitas pembelajaran berpusat pada peserta didik dan dalam model ini, peserta didik bekerja sama dalam tim-tim pembelajaran kooperatif dan mengemban tanggung jawab dalam kelompok, saling membantu satu sama lain, dan saling memberikan dorongan untuk maju, karena keberhasilan kelompok sangat diperhatikan, maka peserta didik yang pandai ikut membantu teman yang lemah dalam kelompoknya (Slavin, 2008: 189). Menurut Slavin (Ratumanan, 2015: 240), TAI terdiri dari delapan komponen, yaitu:
a. Kelompok
b. Tes penempatan
c. Materi kurikulum
d. Belajar kelompok
e. Skor kelompok dan penghargaan kelompok
f. Mengajar kelompok
g. Tes fakta; dan
h. Unit kelas keseluruhan.

Dengan demikian, proses pembelajaran dengan model pembelajaran kooperatif tipe TAI ini diharapkan dapat membuat peserta didik lebih aktif mempelajari materi operasi hitung bilangan pecahan, peserta didik dapat mengasah kemampuan mereka melalui pembelajaran kooperatif yang digabungkan dengan pembelajaran individual sehingga dapat meningkatkan hasil belajar peserta didik.

Berdasarkan latar belakang tersebut, maka rumusan masalah dalam penelitian ini yaitu apakah dengan menggunakan model pembelajaran kooperatif tipe Team Assisted Individualization dapat meningkatkan hasil belajar peserta didik pada materi operasi hitung bilangan pecahan di kelas VII SMP Negeri 4 Ambon?

Adapun tujuan penelitian ini adalah untuk meningkatkan hasil belajar peserta didik pada materi operasi hitung bilangan pecahan melalui model pembelajaran kooperatif tipe Team Assisted Individualization di kelas VII SMP Negeri 4 Ambon.

\section{Metode Penelitian}

Tipe dari penelitian ini adalah penelitian kualitatif dengan menggunakan model penelitian tindakan kelas (classroom actions research). Arikunto (2008: 83), menggambarkan model penelitian ini dalam suatu siklus yang terdiri dari empat tahapan dasar, yaitu perencanaan, pelaksanaan tindakan, observasi atau pengamatan, dan refleksi. Keempat tahapan dasar tersebut dapat digambarkan sebagai berikut. 


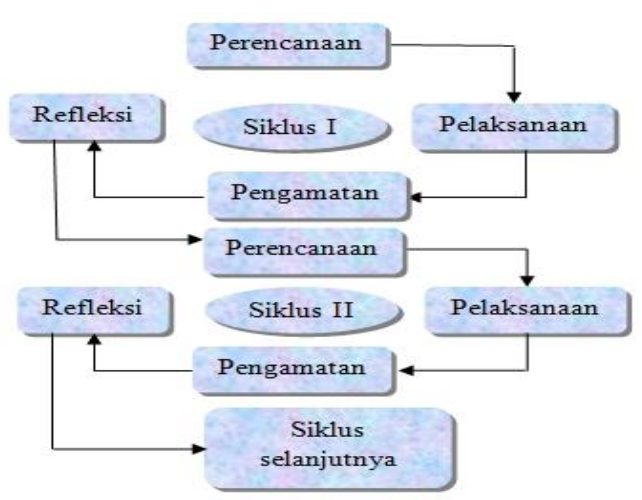

Gambar 1. Siklus Model PTK (Arikunto 2008: 83)

Penelitian tindakan kelas (PTK) ini terdiri dari 2 siklus. Kedua siklus dilaksanakan sesuai dengan perubahan yang ingin dicapai.

Penelitian ini dilaksanakan di SMP Negeri 4 Ambon pada semester ganjil tahun ajaran 2018/2019 sesuai kurikulum sekolah, yaitu Kurikulum 2013. Sumber data dalam penelitian ini adalah peneliti dan peserta didik kelas VII1 SMP Negeri 4 Ambon dengan jumlah 30 orang. Sampai akhir penelitian ini, hanya 22 orang yang datanya lengkap dan data 22 orang inilah yang dianalisis.

Jenis data yang diperoleh adalah data kuantitatif, yaitu hasil tes peserta didik pada akhir tiap siklus, dan data kualitatif, yaitu catatan lembaran observasi pendidik dan peserta didik. Perangkat pembelajaran yang disusun dalam penelitian ini adalah Rencana Pelaksanaan Pembelajaran (RPP), bahan ajar yang disajikan dalam bentuk presentasi powerpoint, dan lembar kerja kelompok. Perangkat pembelajaran ini dipakai untuk empat kali pertemuan.

Adapun instrumen penelitian yang digunakan dalam penelitian ini, yaitu perangkat tes dan lembar observasi untuk pendidik dan peserta didik. Teknik pengumpulan data pada penelitian ini, yaitu tes dan observasi. Sedangkan teknik analisis data, yaitu analisis data kuantitatif dan analisis data kualitatif. Analisis data kuantitatif menggunakan statistik deskriptif untuk mengetahui nilai yang diperoleh setiap peserta didik pada tes akhir siklus. Untuk mengetahui hasil belajar peserta didik, yaitu ketuntasan peserta didik terhadap materi pelajaran, maka rumus yang digunakan adalah sebagai berikut (Purwanto, 2009: 12).

$$
\text { Hasil Belajar }=\frac{\text { Skor yang diperoleh }}{\text { Skor total }} \times 100
$$

Untuk menghitung persentase ketuntasan peserta didik terhadap materi pembelajaran digunakan rumus:

$$
\text { Presentase Ketuntasan Klasikal }=\frac{\text { Jumlah Peserta Didik yang Mencapai KKM }}{\text { Jumlah Seturah Pesetta Didik yang Diteliti }} \times 100
$$

Penelitian tindakan kelas ini dikatakan berhasil jika di dalam kelas tersebut terdapat $65 \%$ dari jumlah seluruh peserta didik telah mencapai nilai KKM, yaitu

Analisis data kualitatif bertujuan untuk memberi kategori, mensistematisir, dan bahkan memproduksi makna oleh peneliti atas apa yang menjadi pusat perhatiannya. Menurut Miles and Huberman, ada tiga langkah analisis data kualitatif (Siregar, 2013: 144), yaitu reduksi data, penyajian data, dan penarikan kesimpulan.

\section{Hasil dan Pembahasan}

Peningkatan hasil belajar pada siklus I secara keseluruhan belum mencapai Kriteria Ketuntasan Minimal (KKM) yang ditetapkan oleh sekolah. Hasil tes akhir siklus I disajikan dalam Tabel 1 berikut.

Tabel 1. Hasil Tes Akhir Siklus I

\begin{tabular}{|c|c|c|c|}
\hline Hasil Belajar & Frekuensi & Persentase & Keterangan \\
\hline$<70$ & 13 & $\frac{13}{22} \times 100 \%=59 \%$ & Belum Tuntas \\
\hline$\geq 70$ & 9 & $\frac{9}{22} \times 100 \%=41 \%$ & Tuntas \\
\hline Jumlah & 22 & $100 \%$ & \\
\hline
\end{tabular}

Berdasarkan Tabel 1 di atas, terlihat bahwa peserta didik yang mencapai KKM, yaitu 9 orang dengan persentase $41 \%$ dan peserta didik yang belum tuntas (tidak mencapai KKM), yaitu 13 orang dengan persentase $59 \%$.

Banyaknya peserta didik yang belum tuntas disebabkan karena kurangnya pemberian motivasi dari peneliti dan kurangnya perhatian peneliti terhadap peserta didik yang takut mengakui bahwa mereka belum mengerti. Beberapa peserta didik juga tidak tuntas karena mereka tidak berani bertanya kepada teman sekelompoknya dan juga kepada peneliti, ada juga yang belum tuntas karena bermain dan tidak serius belajar.

Berdasarkan hasil refleksi pada siklus I, maka akan dilakukan perbaikan pada siklus berikutnya dengan tetap menggunakan model pembelajaran kooperatif tipe Team Assisted Individualization. Hal-hal yang diharapkan dapat dilakukan guna perbaikan pada siklus berikutnya, yaitu: 
a. peneliti harus memperhatikan dan mengelola waktu dengan baik selama proses pembelajaran berlangsung,

b. peneliti harus memotivasi peserta didik dengan baik,

c. peneliti harus mampu mengontrol kelas dan bersikap tegas saat menegur peserta didik yang tidak serius belajar dan mengganggu temannya,

d. peneliti harus lebih cermat mengontrol peserta didik yang lambat mengerti dan malu bertanya saat memerlukan bantuan peneliti untuk menjelaskan,

e. peneliti harus lebih menekankan pentingnya kerjasama dan interaksi antar peserta didik dalam kelompok agar semuanya dapat aktif dan saling membantu menjelaskan di dalam kelompok.

Peningkatan hasil belajar pada siklus II secara keseluruhan telah mencapai kriteria penilaian dan menunjukkan adanya peningkatan jika dibandingkan dengan hasil tes siklus I. Hasil tes akhir siklus II telah disajikan dalam Tabel 2 sebagai berikut.

Tabel 2. Hasil Tes Akhir Siklus II

\begin{tabular}{|c|c|c|c|}
\hline Hasil Belajar & Frekuensi & Persentase & Keterangan \\
\hline$<70$ & 6 & $\frac{6}{22} \times 100 \%=27 \%$ & Belum Tuntas \\
\hline$\geq 70$ & 16 & $\frac{16}{22} \times 100 \%=73 \%$ & Tuntas \\
\hline Jumlah & 22 & $100 \%$ & \\
\hline
\end{tabular}

Berdasarkan Tabel 2 di atas, terlihat peserta didik yang mencapai KKM yaitu 16 orang dengan persentase $73 \%$ dan peserta didik yang belum mencapai KKM, yaitu 6 orang dengan persentase $27 \%$.

Berdasarkan hasil tes akhir siklus II, maka peneliti, pendidik senior, dan keempat observer menilai bahwa pelaksanaan tindakan perbaikan telah berhasil dilaksanakan, sehingga tidak dilanjutkan lagi ke siklus berikutnya. Untuk keenam peserta didik yang belum tuntas, peneliti dan pendidik sepakat untuk memberikan remedial diluar jam belajar mengajar dan memberikan tugas untuk dikerjakan di rumah. Peningkatan hasil belajar yang terjadi dari siklus I hingga siklus II pada penelitian ini, disajikan dalam diagram di bawah ini.

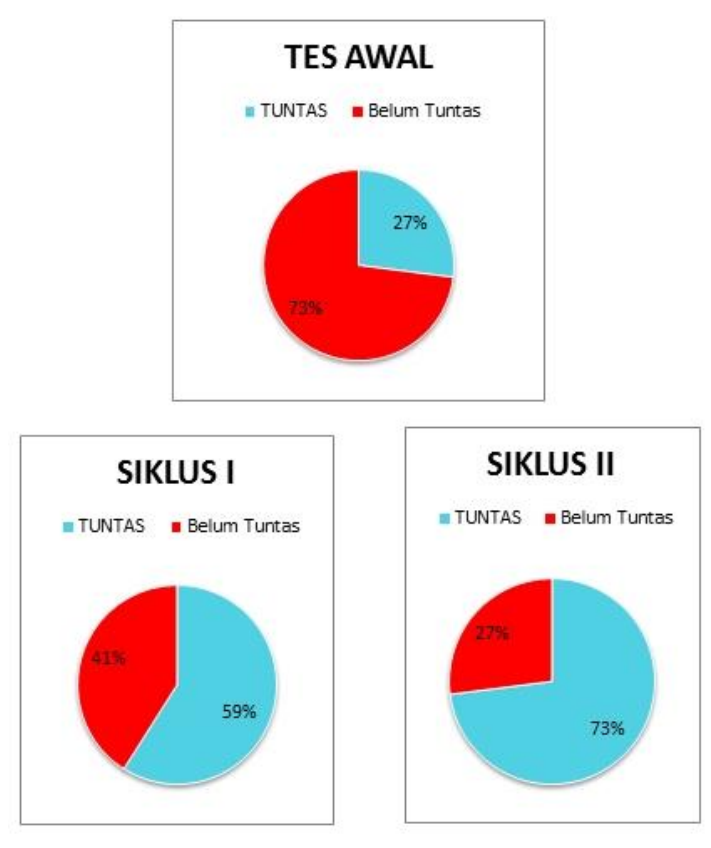

Gambar 1. Diagram persentase ketuntasan hasil belajar peserta didik

Dengan demikian, dapat disimpulkan bahwa model pembelajaran yang diterapkan peneliti telah maksimal. Proses pembelajaran yang ditetapkan, sudah sesuai dengan RPP yang disusun berdasarkan model pembelajaran kooperatif tipe Team Assisted Individualization.

Berdasarkan hasil tes akhir siklus I, maka penelitian dilanjutkan ke siklus II karena belum lebih dari sama dengan $65 \%$ peserta didik yang mencapai KKM. Pelaksanaan tindakan pada siklus II berpatokan pada perbaikan kekurangan-kekurangan siklus I. Kekurangan pada siklus I sudah diperbaiki dengan baik oleh peneliti. Peneliti sudah dapat mengelola waktu dengan baik sesuai RPP. Peneliti juga sudah memberikan motivasi baik secara klasikal maupun secara individual pada peserta didik di dalam kelompok, sehingga peserta didik mau bekerja sama, aktif berdiskusi dan bertanya, serta berusaha menyelesaikan soal-soal pada LKK. Kondisi kelas juga sudah tertib karena peneliti dengan tegas menegur peserta didik yang tidak aktif dalam kelompok dan bercerita saat proses diskusi berlangsung. Perbaikan dan pelaksanaan tindakan ini telah mencapai KKM yang ditetapkan sekolah. Hal tersebut terlihat dari hasil tes akhir siklus II.

Pembelajaran siklus II menunjukkan adanya peningkatan hasil belajar. Hal ini terlihat dari hasil observasi peneliti saat mengajar, observasi peserta didik saat belajar dan berdiskusi, serta hasil tes akhir siklus II yang mencapai KKM. Hasil tes siklus II menunjukkan bahwa peserta didik yang tuntas mencapai Kriteria Ketuntasan Minimal (KKM) lebih dari sama dengan 70 adalah 16 peserta didik dengan 
persentase $73 \%$ dan peserta didik yang belum tuntas mencapai KKM kurang dari 70 adalah 6 peserta didik dengan persentase $27 \%$. Peningkatan hasil belajar dari tes awal sampai dengan tes akhir siklus II disajikan dalam Gambar 2 berikut ini.

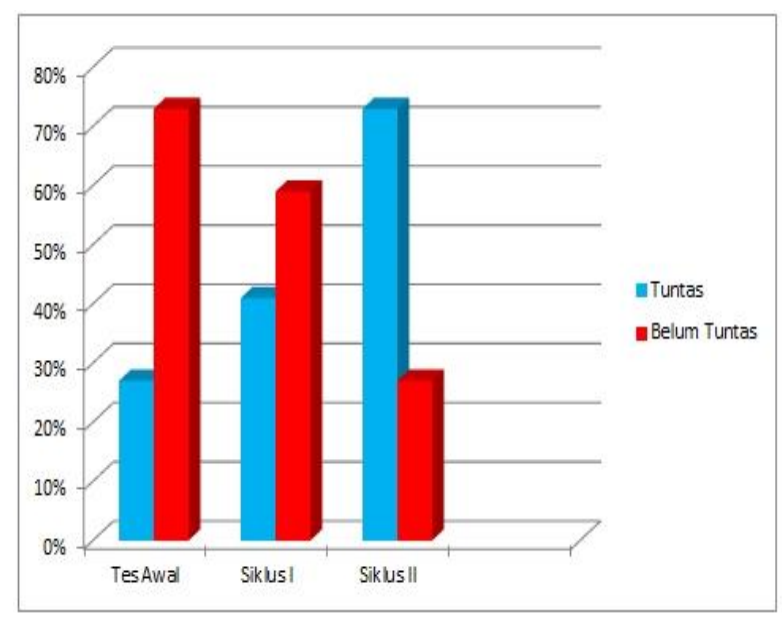

Gambar 2. Peningkatan hasil belajar dari tes awal sampai dengan tes skhir siklus II

Berdasarkan hasil tes akhir siklus II yang diperoleh, dapat dilihat bahwa pelaksanaan tindakan pada siklus II telah dilakukan dengan baik dan telah mencapai kriteria ketuntasan yang ditentukan, yaitu $65 \%$ peserta didik harus memperoleh nilai lebih dari atau sama dengan 70 . Karena telah mencapai kriteria ketuntasan, maka penelitian ini berakhir pada siklus II.

Dengan demikian, berdasarkan hasil yang diperoleh dan dengan adanya peningkatan pada siklus II, maka dapat disimpulkan bahwa model pembelajaran kooperatif tipe team assisted individualization yang telah diterapkan oleh peneliti pada pembelajaran di kelas VII1 telah terlaksana dengan baik. Pelaksanaan tindakan juga telah dilakukan dengan baik. Hal ini menunjukkan bahwa hipotesis tindakan telah tercapai, yaitu ada peningkatan hasil belajar peserta didik pada materi operasi hitung pecahan (penjumlahan, pengurangan, perkalian, dan pembagian pecahan biasa, pecahan campuran, dan pecahan desimal) dengan menggunakan model pembelajaran kooperatif tipe team assisted individualization.

\section{Kesimpulan}

Berdasarkan hasil dan pembahasan, maka dapat disimpulkan bahwa dengan menggunakan model pembelajaran kooperatif tipe team assisted individualization, hasil belajar peserta didik kelas VII1 SMP Negeri 4 Ambon pada materi operasi hitung bilangan pecahan dapat ditingkatkan. Hal ini terlihat dari hasil yang diperoleh setelah pelaksanaan tindakan pada siklus I diperoleh $41 \%$ peserta didik yang mencapai Kriteria Ketuntasan
Minimal (KKM), Kemudian, pelaksanaan tindakan pada siklus II meningkat menjadi $73 \%$ peserta didik yang mencapai KKM.

\section{Daftar Pustaka}

Arikunto. (2008). Prosedur Penelitian Suatu Praktik. Jakarta: Rineka Cipta.

Purwanto. (2009). Evaluasi Hasil Belajar. Yogyakarta: Pustaka Pelajar.

Ratumanan, T, G. (2015). Belajar dan Pembelajaran serta Faktor-Faktor yang Mempengaruhinya. Yogyakarta: Pensil Komunika.

Siregar, Syofian. (2013). Satatistik Parametrik untuk Penelitian Kuantitatif. Jakarta: Bumi Aksara.

Slavin, R, E. (2008). Cooperative Learning: Teori, Riset, Dan Praktik. Bandung: Nusa Media.

Trianto. (2009). Mendesain Model Pembelajaran Inovatif-Progresif: Konsep, Landasan, Dan Implementasinya Pada Kurikulum Tingkat Satuan Pendidikan (KTSP). Jakarta: Kencana. 
